\title{
Association of Egr3 genetic polymorphisms and coronary artery disease in the Uygur and Han of China
}

\author{
Xia Li ${ }^{1 \dagger}$, Yi-Tong Ma ${ }^{1 *}$, Xiang Xie ${ }^{1 \dagger}$, Yi-Ning Yang ${ }^{1}$, Xiang Ma' ${ }^{1}$ Ying-Ying Zheng ${ }^{1}$, Shuo Pan ${ }^{1}$, Fen Liu ${ }^{2}$ \\ and Bang-Dang Chen ${ }^{2}$
}

\begin{abstract}
Background: Endothelial cell activation and dysfunction are the foundation of atherosclerosis, including coronary artery disease (CAD). Endothelial cell activation is mediated by the level of gene transcription. Early growth response 3 (Egr3) is a critical determinant of vascular endothelial growth factor (VEGF) signalling in activated endothelial cells. If endothelial cells are excessively activated, it may lead to vasculopathic diseases, such as pathologic angiogenesis, inflammation, and atherosclerosis. The aim of the present study was to assess the association between the Egr3 gene polymorphisms and CAD.

Methods: Two independent case-control studies that involved the Han group (409 CAD patients and 351 control subjects) and the Uygur group (299 CAD patients and 303 control subjects) analysed the relationship between Egr3 SNPs (rs1996147 and rs1008949) and CAD. Genotyping was undertaken using the TaqMan SNP genotyping assay.

Results: The entire Uygur group and the males in the Uygur group showed a higher frequency of the A allele (rs 1996147) in CAD patients than in the control subjects ( $P=0.003$ and $P=0.005$, respectively). Additionally, the distribution of the recessive model of rs 1996147 (AA vs $G G+A G$ ) for the total sample and the males was significantly different between CAD patients and control participants ( $P=0.002$ and $P=0.003$, respectively), and the difference remained statistically significant following multivariate adjustment (Total: $\mathrm{OR}=1.705 ; 95 \% \mathrm{Cl}: 1.166-2.494, P=0.006$; males: $\mathrm{OR}=1.908,95 \% \mathrm{Cl}: 1.189-3.062, P=0.007)$. However, for Uygur females, we did not observe a difference in the allele frequency or genotypic distribution of rs 1996147 between CAD patients and control participants. Similarly, the distribution of the rs1996147 allele frequency or genotypes showed no significant difference between patients with CAD and control participants in the Han group. The distribution of rs 1008949 genotypes, dominant model, recessive model, and allele frequency did not show a significant difference between patients with CAD and the control subjects in the Han and Uygur groups.
\end{abstract}

Conclusion: rs1996147 may be a novel polymorphism of the Egr3 gene associated with CAD in males of the Chinese Uygur population.

Keywords: Egr3, Coronary artery disease, Polymorphism

\footnotetext{
*Correspondence: myt_xj@sina.com

${ }^{\dagger}$ Equal contributors

'Department of Cardiology, First Affiliated Hospital of Xinjiang Medical

University, Urumqi, Xinjiang 830054, China

Full list of author information is available at the end of the article
}

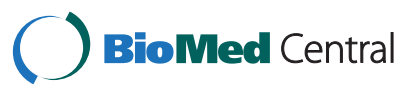

(c) 2014 Li et al.; licensee BioMed Central Ltd. This is an Open Access article distributed under the terms of the Creative Commons Attribution License (http://creativecommons.org/licenses/by/4.0), which permits unrestricted use, distribution, and reproduction in any medium, provided the original work is properly credited. The Creative Commons Public Domain Dedication waiver (http://creativecommons.org/publicdomain/zero/1.0/) applies to the data made available in this article, unless otherwise stated. 


\section{Background}

Coronary artery disease (CAD) is thought to be a complex multifactorial and polygenic disorder resulting from interactions between an individual's genetic makeup and various environmental factors [1]. Epidemiology investigations have revealed that some genetic variants, such as polymorphisms in the renin angiotensin system [2], apolipoprotein E [3], blood coagulation factors [4], and inflammation factors [5], increase the risk of coronary artery disease (CAD).

The early growth response ( $E g r)$ family of transcription factors (Egr1 to Egr4) is the nuclear regulator of endothelial cell activation. Egr1, 2, and 3 are transcriptional activators, whereas Egr4 is a transcriptional repressor. The activation of target gene transcription by Egr family members requires their de novo protein synthesis [6]. Egr3 is a member of a zinc finger transcription factor subfamily, which was found to be strongly upregulated by vascular endothelial growth factor (VEGF) in an oligonucleotide microarray screen of endothelial cells [7]. Recent evidence points to a role for Egr3 in transducing signals in endothelial cells and is one of the most highly inducible genes in VEGF-treated endothelial cells $[8,9]$. The role of VEGF in atherosclerosis is a subject of debate in the literature. Some studies show that the administration of recombinant human VEGF in animals enhances the progression of atherosclerotic plaque [10], whereas others observed that it acts as an antiatherosclerotic factor, promoting re-endothelisation, reducing intimal thickening and preventing thrombus formation [11]. Suehiro and colleagues [6] show that VEGF-induced endothelial activities are mediated by the activation of the Egr3 transcription factor. Egr3 is rapidly induced by extracellular stimuli and has been implicated in the proliferation and differentiation of several different cell types, including endothelial cells [6]. Liu D et al. [7] reported that VEGF induced a rapid increase in Egrdependent transcriptional activation mediated via its major signalling receptor, tyrosine-kinase receptors KDR (VEGFR2), and the protein kinase C (PKC) pathway. The inhibition of Egr3 gene expression by RNA interference was effective in inhibiting basal and VEGF-induced Egr3 gene expression, and it also inhibited VEGF-mediated endothelial cell proliferation, migration, and tubulogenesis. These findings indicate that Egr3 has an essential downstream role in VEGF-mediated endothelial functions that lead to angiogenesis and may have particular relevance for adult angiogenic processes involved in vascular repair and neovascular disease. However, the role of Egr3 in atherosclerosis remains unknown.

Previous studies have shown that the quantification of amplified Egr3 fragments leads to a significant increase in expression following $3 \mathrm{~h}$ of ischemia, with a maximum increase (5-fold) at $24 \mathrm{~h}$ in a mouse survival model of ischemia [12]. Therefore, Egr3 may be an important contributor to the development and progression of atherosclerotic disease. Accordingly, we screened for possible mutations and polymorphisms of the Egr3 gene and assessed the association between the genotypes of this gene and CAD in a Chinese Uygur and Han population.

\section{Methods}

All patients gave written informed consent and explicitly provided permission for DNA analyses as well as for the collection of relevant clinical data. The study protocols were approved by the Ethics Committees of the First Affiliated Hospital of Xinjiang Medical University.

\section{Subjects}

Two patient populations (Han and Uygur) with CAD were studied independently. All patients were recruited at the First Affiliated Hospital of Xinjiang Medical University from 2007 to 2010. The study participants included 409 Han patients and 299 Uygur patients diagnosed with CAD. All of the CAD patients were defined by angiographic means (main coronary artery stenosis of $>50 \%$ ). For each CAD patient group, we selected healthy controls matched for ethnicity, sex, and age. Control subjects were selected from the cardiovascular risk survey (CRS) $[13,14]$. Briefly, the CRS is a prospective, observational cohort study designed to investigate the prevalence, incidence, and risk factors of cardiovascular disease in the Han, Uygur, and Kazakh populations in Xinjiang of China from October 2007 to March 2010. Control participants included Han $(\mathrm{n}=351)$ and Uygur $(\mathrm{n}=303)$ individuals who did not have coronary vessel stenosis and did not show clinical or electrocardiographic evidence of myocardial infarction (MI) or CAD. All patients with impaired renal function, malignancy, connective tissue disease, schizophrenia, or chronic inflammatory disease were excluded. Diabetes, hypertension, hyperlipidemia, smoking, and alcohol consumption were defined as previously described [15-17].

\section{Biochemical analysis}

We measured the plasma concentration of blood triglycerides (TG), total cholesterol (TC), high-density lipoprotein (HDL), and low-density lipoprotein (LDL) using standard methods in the Clinical Laboratory Department of the First Affiliated Hospital, Xinjiang Medical University as described previously $[17,18]$.

\section{SNP selection}

We selected two single-nucleotide polymorphisms (SNPs) in the human Egr3 gene as markers for assessment of genetic association. There are 103 SNPs in the human Egr3 gene listed in the National Center for Biotechnology 
Information SNP database (www.ncbi.nlm.nih.gov/SNP). Using the Haploview 4.2 software and the HapMap phrase II database, we obtained two tagging SNPs (rs1996147, rs1008949) for Chinese Hans and Uygurs using minor allele frequency (MAF) $\geq 0.05$ and linkage disequilibrium patterns, with $\mathrm{r}^{2} \geq 0.8$ as a cut-off.

\section{Genotyping}

Blood samples were collected from all participants. Genomic DNA was extracted from peripheral blood leukocytes using phenol and chloroform [19]. Genotyping was undertaken using TaqMan SNP genotyping assays (Applied Biosystems [ABI], Foster City, California), which were performed using Taq amplification [20]. In the first step of the $5^{\prime}$ nuclease assay, allele-specific fluorogenic probes were hybridised to the template. Subsequently, the 5' nuclease activity of the Taq polymerase made it possible for discrimination during the polymerase chain reaction (PCR). The probes contain a 3'minor groovebinding group that hybridises to single-stranded targets and has greater sequence specificity than the standard DNA probes. This reduces nonspecific probe hybridisation, thereby resulting in low background fluorescence for the 5' nuclease PCR assay (TaqMan; Applied Biosystems). Cleavage results in the increased emission of a reporter dye. Each 5' nuclease assay requires two unlabelled PCR primers and two allele-specific probes. Each probe is labelled with two reporter dyes at the 5' end. In the present study, VIC and FAM were used as the reporter dyes. The primers and probes used in the TaqMan SNP genotyping assays (Applied Biosystems) were chosen based on information from the ABI website (http://appliedbiosystems.com.cn/).

PCR amplification was performed using $6 \mu \mathrm{L}$ of TaqMan Universal Master Mix, No AmpErase UNG (2x; $\mathrm{ABI}$ ) in a $12-\mu \mathrm{L}$ final reaction volume containing $2 \mathrm{ng}$ of DNA, $0.22 \mu \mathrm{L}$ of TaqMan SNP genotyping assay mix $(20 \times$ or $40 \times)$, primers at a concentration of $900 \mathrm{nmol} / \mathrm{L}$ each, and probes at a final concentration of $200 \mathrm{nmol} / \mathrm{L}$ each. The thermal cycling conditions were as follows: $50^{\circ} \mathrm{C}$ for 2 minutes, $95^{\circ} \mathrm{C}$ for 10 minutes, 40 cycles of $95^{\circ} \mathrm{C}$ for 15 seconds, and $62^{\circ} \mathrm{C}$ for 1 minute. Thermal cycling was performed using the GeneAmp 7900 system. Plates were read on the sequence detection systems (SDS) automation controller software v2.4 (ABI).

\section{Statistical analysis}

Data analysis was performed using Statistical Package for Social Sciences SPSS for Windows (version 17.0). Hardy-Weinberg equilibrium was assessed using $X^{2}$ analysis. All continuous variables were expressed as the mean \pm standard deviation (SD). The differences between the CAD patients and the control participants were assessed using independent samples $t$ test. Differences in enumeration data between CAD patients and control participants were analysed using the $\mathrm{X}^{2}$ test. Categorical variables, such as allele and genotype frequencies among CAD cases and controls were compared using the chisquare test. Additionally, logistic regression analysis was performed to assess the odds ratio (OR) and its 95\% confidence interval $(\mathrm{CI})$ as a measure of the association between the Egr3 polymorphism and risk of CAD. A value of $P<0.05$ was considered significant.

\section{Results}

Table 1 shows the clinical characteristics of CAD patients and control subjects in the Han population. For the total sample and for male and female participants, there were no significant differences in age, body mass index (BMI), pulse and serum concentration of TG and HDL-C between patients with CAD and control participants. For total subjects, males, and females, the following values were significantly higher for the CAD patients compared with the control subjects: LDL-C, incidence of diabetes, and smoking (all $P<0.05$ ). For total subjects and males, the serum concentration of total cholesterol was significantly higher for the CAD patients compared with the control subjects. However, for females, there was no difference between CAD patients and control participants. For males, the prevalence of essential hypertension $(\mathrm{EH})$ was not significant $(P>0.05)$; however, it was higher for patients with $C A D$ than for the control participants, total subjects and females $(P<0.05)$.

Table 2 shows the clinical characteristics of CAD patients and control subjects in the Uygur population. For total subjects, males, and females, the following values were significantly higher for the CAD patients compared with the control subjects: the serum concentration of total cholesterol and LDL-C and smoking $(P<0.05)$. For total subjects and male and female participants, there was no significant difference in the following variables between CAD patients and control subjects: age, BMI, pulse, triglycerides, EH, and DM (all $P>0.05$ ). The serum concentration of HDL-C only showed a significant difference between patients with $\mathrm{CAD}$ and female control participants in the Uygur population $(P<0.05)$.

Tables 3 and 4 show the distribution of the genotypes and alleles for the two SNPs of Egr3 gene in the Han and Uygur populations. The genotypic distribution for each of the SNPs was in agreement with the predicted Hardy-Weinberg equilibrium values for both ethnicities $(P>0.05$ in the CAD and control groups, data not shown).

For the total participants in the Uygur group, the distribution of rs1996147 genotypes showed a significant difference between patients with CAD and control participants $(P=0.003)$. Additionally, the distribution of the dominant model (GG vs AA $+\mathrm{AG}$ ), recessive model 
Table 1 Characteristics of study participants in the Han population

\begin{tabular}{|c|c|c|c|c|c|c|c|c|c|}
\hline & \multicolumn{3}{|c|}{ Total } & \multicolumn{3}{|c|}{ Men } & \multicolumn{3}{|c|}{ Women } \\
\hline & $\begin{array}{c}\text { CAD } \\
\text { patients }\end{array}$ & $\begin{array}{l}\text { Control } \\
\text { subjects }\end{array}$ & $P$ value & $\begin{array}{c}\text { CAD } \\
\text { patients }\end{array}$ & $\begin{array}{l}\text { Control } \\
\text { subjects }\end{array}$ & $P$ value & $\begin{array}{c}\text { CAD } \\
\text { patients }\end{array}$ & $\begin{array}{l}\text { Control } \\
\text { subjects }\end{array}$ & $P$ value \\
\hline Number of subjects(n) & 409 & 351 & & 300 & 179 & & 109 & 172 & \\
\hline Age(years), mean(SD) & $57.06(10.41)$ & $56.58(9.5)$ & 0.510 & $56.97(10.89)$ & $56.03(10.05)$ & 0.348 & $57.64(9.75)$ & $57.16(9.35)$ & 0.680 \\
\hline BMI $\left(\mathrm{kg} / \mathrm{m}^{2}\right)$,mean(SD) & $25.60(3.29)$ & $26.06(3.51)$ & 0.060 & $25.72(3.34)$ & $26.47(3.33)$ & 0.016 & $25.26(3.13)$ & $25.63(3.66)$ & 0.380 \\
\hline Pulse (beats/min),mean(SD) & $72.51(10.90)$ & 72.97(10.28) & 0.547 & $72.19(10.94)$ & $74.09(11.46)$ & 0.072 & 73.34(10.79) & $71.81(8.77)$ & 0.185 \\
\hline Total cholesterol (mmol/L),mean(SD) & $4.50(0.91)$ & $4.37(0.99)$ & $0.047^{*}$ & $4.44(0.88)$ & $4.25(1.25)$ & $0.031^{*}$ & 4.68(0.97) & $4.46(0.93)$ & 0.058 \\
\hline Triglycerides (mmol/L), mean(SD) & $1.84(1.14)$ & $1.77(1.25)$ & 0.483 & $1.80(1.08)$ & $1.86(1.45)$ & 0.058 & $1.92(1.30)$ & $1.68(0.99)$ & 0.085 \\
\hline LDL (mmol/L),mean(SD) & $2.49(0.91)$ & $2.13(0.83)$ & $<0.001^{*}$ & $2.53(0.77)$ & $2.32(0.87)$ & $0.006^{*}$ & $2.47(1.02)$ & $2.03(0.78)$ & $<0.001^{*}$ \\
\hline $\mathrm{HDL}(\mathrm{mmol} / \mathrm{L})$,mean(SD) & $1.17(0.49)$ & $1.23(0.51)$ & 0.095 & $1.13(0.51)$ & $1.15(0.54)$ & 0.733 & $1.26(0.39)$ & $1.31(0.47)$ & 0.374 \\
\hline $\mathrm{EH}, \mathrm{n}(\%)$ & $220(53.8)$ & $163(46.4)$ & $0.043^{*}$ & 151(50.3) & $80(44.7)$ & 0.232 & $69(63.3)$ & $83(48.3)$ & $0.014^{*}$ \\
\hline DM (\%) & $102(24.9)$ & $39(11.1)$ & $<0.001^{*}$ & $70(23.3)$ & 20(11.2) & $<0.001^{*}$ & $32(29.4)$ & 19(11.0) & $<0.001^{*}$ \\
\hline Smoking (\%) & $230(56.2)$ & $87(24.8)$ & $<0.001^{*}$ & 208(69.3) & $83(46.4)$ & $<0.001^{*}$ & $22(20.2)$ & $4(2.3)$ & $<0.001^{*}$ \\
\hline
\end{tabular}

Continuous variables are expressed as mean \pm s.d. Categorical variables are expressed as percentages.

$C A D$, coronary artery disease; BMI, body mass index; LDL, Low-density lipoprotein; HDL, high-density lipoprotein; EH, essential hypertension; DM, diabetes mellitus. The $P$ value of the continuous variables was calculated by the independent samples $t$ test

The $P$ value of the categorical variables was calculated by $X^{2}$ test. ${ }^{*} P<0.05$.

(AA vs GG + AG), and allele frequency of rs1996147 showed significant differences between patients with CAD and control subjects $(P=0.018, P=0.002$, and $P=0.001$, respectively). For the males in the Uygur group, the distribution of rs1996147 genotypes, dominant model (GG vs $\mathrm{AA}+\mathrm{AG}$ ), recessive model (AA vs $\mathrm{GG}+\mathrm{AG}$ ), and allele frequency of rs1996147 were significantly higher in the CAD group than in the control participants $(P=0.005$, $P=0.021, P=0.003$, and $P=0.001$, respectively). There was no significant difference between the CAD group and the control subjects in the Uygur females in the distribution of rs1996147 genotypes, dominant model
(GG vs $\mathrm{AA}+\mathrm{AG}$ ), recessive model (AA vs $\mathrm{GG}+\mathrm{AG}$ ), and allelic distribution $(P>0.05)$. Moreover, for total participants, males and females in the Uygur group, the distribution of rs1008949 genotypes, dominant model (CC vs $\mathrm{TT}+\mathrm{CT}$ ), recessive model (TT vs $\mathrm{AA}+\mathrm{CT}$ ), and allele frequency did not show significant differences between patients with CAD and control subjects $(P>0.05)$. Similarly, for total participants, males and females in the Han group, the distribution of two SNPs (rs1996147 and rs1008949), dominant model, recessive model, and allele frequency showed no significant differences between patients with CAD and control participants $(P>0.05)$.

Table 2 Characteristics of study participants in the Uygur population

\begin{tabular}{|c|c|c|c|c|c|c|c|c|c|}
\hline & \multicolumn{3}{|c|}{ Total } & \multicolumn{3}{|c|}{ Men } & \multicolumn{3}{|c|}{ Women } \\
\hline & $\begin{array}{c}\text { CAD } \\
\text { patients }\end{array}$ & $\begin{array}{l}\text { Control } \\
\text { subjects }\end{array}$ & $P$ value & $\begin{array}{c}\text { CAD } \\
\text { patients }\end{array}$ & $\begin{array}{l}\text { Control } \\
\text { subjects }\end{array}$ & $P$ value & $\begin{array}{c}\text { CAD } \\
\text { patients }\end{array}$ & $\begin{array}{l}\text { Control } \\
\text { subjects }\end{array}$ & $P$ value \\
\hline Number of subjects(n) & 299 & 303 & & 198 & 196 & & 101 & 107 & \\
\hline Age (years),mean(SD) & $57.32(8.54)$ & $56.78(8.89)$ & 0.447 & $56.82(8.49)$ & $56.02(8.56)$ & 0.352 & $58.02(8.62)$ & $57.13(8.96)$ & 0.467 \\
\hline BMI $\left(\mathrm{kg} / \mathrm{m}^{2}\right)$, mean(SD) & $26.05(3.55)$ & $25.89(4.21)$ & 0.615 & $26.29(3.59)$ & 26.11(4.06) & 0.641 & 25.95(3.02) & $25.02(4.31)$ & 0.075 \\
\hline Pulse (beats/min),mean(SD) & $76.06(10.49)$ & $75.02(11.93)$ & 0.212 & $75.70(10.51)$ & $74.74(12.80)$ & 0.420 & $77.08(10.43)$ & $75.52(10.20)$ & 0.278 \\
\hline Total cholesterol (mmol/L),mean(SD) & $4.74(0.94)$ & $4.25(0.90)$ & $<0.001^{*}$ & $4.72(0.83)$ & $4.13(0.90)$ & $<0.001^{*}$ & $4.77(1.23)$ & $4.45(0.90)$ & $0.023^{*}$ \\
\hline Triglycerides (mmol/L),mean(SD) & $1.85(0.95)$ & $1.82(1.12)$ & 0.766 & $1.78(0.93)$ & $1.84(1.08)$ & 0.578 & $1.98(0.98)$ & $1.80(1.21)$ & 0.233 \\
\hline LDL (mmol/L),mean(SD) & $2.74(0.81)$ & $2.48(1.12)$ & $0.001^{*}$ & $2.71(0.79)$ & $2.45(1.26)$ & $0.017^{*}$ & $2.80(0.84)$ & $2.53(0.80)$ & $0.019^{*}$ \\
\hline $\mathrm{HDL}(\mathrm{mmol} / \mathrm{L})$, mean(SD) & $0.99(0.33)$ & $1.06(0.53)$ & 0.054 & $0.99(0.33)$ & $1.05(0.63)$ & 0.232 & $1.01(0.32)$ & $1.09(0.27)$ & $0.039^{*}$ \\
\hline Hypertension (\%) & $134(44.8)$ & $123(40.6)$ & 0.295 & $86(43.4)$ & $77(39.5)$ & 0.427 & $48(47.5)$ & $46(43.0)$ & 0.511 \\
\hline $\mathrm{DM}(\%)$ & $58(19.4)$ & $41(13.5)$ & 0.052 & $38(19.2)$ & $25(12.8)$ & 0.081 & $20(19.8)$ & $16(15.0)$ & 0.356 \\
\hline Smoking (\%) & $195(65.2)$ & $116(38.6)$ & $<0.001^{*}$ & $145(73.2)$ & $96(49.0)$ & $<0.001^{*}$ & $50(49.5)$ & 21(19.6) & $<0.001^{*}$ \\
\hline
\end{tabular}

Continuous variables are expressed as mean \pm s.d. Categorical variables are expressed as percentages. CAD, coronary artery disease; BMI, body mass index; $\mathrm{LDL}$, Low-density lipoprotein; HDL, high-density lipoprotein; DM, diabetes mellitus; The $P$ value of the continuous variables was calculated by the independent samples $t$ test. The $P$ value of the categorical variables was calculated by $X^{2}$ test. ${ }^{*} P<0.05$. 
Table 3 Genotyping and allele distributions in control subjects and patients with CAD in the Han population

\begin{tabular}{|c|c|c|c|c|c|c|c|c|c|}
\hline \multirow[b]{2}{*}{ Variants } & \multicolumn{3}{|c|}{ Total } & \multicolumn{3}{|c|}{ Men } & \multicolumn{3}{|c|}{ Women } \\
\hline & $\begin{array}{c}\text { CAD } \\
\text { patients }\end{array}$ & $\begin{array}{l}\text { Control } \\
\text { subjects }\end{array}$ & $P$ value & $\begin{array}{c}\text { CAD } \\
\text { patients }\end{array}$ & $\begin{array}{l}\text { Control } \\
\text { subjects }\end{array}$ & $P$ value & $\begin{array}{c}\text { CAD } \\
\text { patients }\end{array}$ & $\begin{array}{l}\text { Control } \\
\text { subjects }\end{array}$ & $P$ value \\
\hline \multicolumn{10}{|c|}{ rs1996147 } \\
\hline \multicolumn{10}{|c|}{ Genotyping } \\
\hline AA & $45(11.0 \%)$ & $49(14.0 \%)$ & & $35(11.7 \%)$ & $28(15.6 \%)$ & & $10(9.2 \%)$ & $21(12.2 \%)$ & \\
\hline$A G$ & 199(48.7\%) & $156(44.4 \%)$ & & $150(50.0 \%)$ & $77(43.1 \%)$ & & 49(45.0\%) & 79(45.9\%) & \\
\hline GG & $165(40.3 \%)$ & $146(41.6 \%)$ & 0.346 & 115(38.3\%) & $74(41.3 \%)$ & 0.252 & $50(45.8 \%)$ & $72(41.9 \%)$ & 0.664 \\
\hline \multicolumn{10}{|c|}{ Dominant model } \\
\hline GG & $165(40.3 \%)$ & $146(41.6 \%)$ & & 115(38.3\%) & $74(41.3 \%)$ & & $50(45.8 \%)$ & $72(41.9 \%)$ & \\
\hline$A A+A G$ & $244(59.7 \%)$ & 205(58.4\%) & 0.726 & 185(61.7\%) & 105(58.7\%) & 0.515 & $59(54.2 \%)$ & $100(58.1 \%)$ & 0.509 \\
\hline \multicolumn{10}{|c|}{ Recessive model } \\
\hline AA & $45(11.0 \%)$ & 49(14.0\%) & & $35(11.7 \%)$ & $28(15.6 \%)$ & & $10(9.2 \%)$ & $21(12.2 \%)$ & \\
\hline $\mathrm{GG}+\mathrm{AG}$ & 364(89.0\%) & $302(86.0 \%)$ & 0.217 & 265(88.3\%) & $151(84.4 \%)$ & 0.213 & 99(90.8\%) & 151(87.8\%) & 0.429 \\
\hline \multicolumn{10}{|c|}{ Additive model } \\
\hline$A G$ & 199(48.7\%) & $156(44.4 \%)$ & & $150(50.0 \%)$ & $77(43.1 \%)$ & & 49(45.0\%) & 79(45.9\%) & \\
\hline$A A+G G$ & $210(51.3 \%)$ & 195(55.6\%) & 0.246 & 150(50.0\%) & 102(56.9\%) & 0.139 & $60(55.0 \%)$ & $93(54.1 \%)$ & 0.873 \\
\hline \multicolumn{10}{|l|}{ Allele } \\
\hline A & 289(35.3\%) & 254(36.2\%) & & $220(36.7 \%)$ & 133(37.2\%) & & 69(31.7\%) & $121(35.2 \%)$ & \\
\hline G & $529(64.7 \%)$ & $448(63.8 \%)$ & 0.730 & $380(63.3 \%)$ & $225(62.8 \%)$ & 0.881 & 149(68.3\%) & $223(64.8 \%)$ & 0.390 \\
\hline \multicolumn{10}{|c|}{ rs1008949 } \\
\hline \multicolumn{10}{|c|}{ Genotyping } \\
\hline $\mathrm{CC}$ & $112(27.4 \%)$ & $99(28.2 \%)$ & & $85(28.3 \%)$ & $55(30.7 \%)$ & & $30(27.5 \%)$ & $44(25.6 \%)$ & \\
\hline $\mathrm{CT}$ & 204(49.9\%) & $173(49.3 \%)$ & & 149(49.7\%) & $84(46.9 \%)$ & & $55(50.5 \%)$ & $89(51.7 \%)$ & \\
\hline$\pi$ & $93(22.7 \%)$ & $79(22.5 \%)$ & 0.969 & $69(23.0 \%)$ & $40(22.4 \%)$ & 0.817 & $24(22.0 \%)$ & $39(22.7 \%)$ & 1.000 \\
\hline \multicolumn{10}{|c|}{ Dominant model } \\
\hline$C C$ & $112(27.4 \%)$ & $99(28.2 \%)$ & & $85(28.3 \%)$ & $55(30.7 \%)$ & & $30(27.5 \%)$ & $44(25.6 \%)$ & \\
\hline$\pi+C T$ & $297(72.6 \%)$ & $252(71.8 \%)$ & 0.801 & 218(72.7\%) & 124(69.3\%) & 0.532 & 79(72.5\%) & $128(74.4 \%)$ & 0.719 \\
\hline \multicolumn{10}{|c|}{ Recessive model } \\
\hline$\pi$ & $93(22.7 \%)$ & $79(22.5 \%)$ & & 69(23.0\%) & $40(22.4 \%)$ & & $24(22.0 \%)$ & $39(22.7 \%)$ & \\
\hline $\mathrm{CC}+\mathrm{CT}$ & $316(77.3 \%)$ & $272(77.5 \%)$ & 0.939 & 234(77.0\%) & 139(77.6\%) & 0.914 & 85(78.0\%) & 133(77.3\%) & 0.995 \\
\hline \multicolumn{10}{|c|}{ Additive model } \\
\hline $\mathrm{CT}$ & 204(49.9\%) & $173(49.3 \%)$ & & 149(46.7\%) & $84(46.9 \%)$ & & $55(50.5 \%)$ & $89(51.7 \%)$ & \\
\hline$C C+\pi$ & $205(50.1 \%)$ & $178(50.7 \%)$ & 0.871 & 154(51.3\%) & $95(53.1 \%)$ & 0.633 & $54(49.5 \%)$ & $83(48.3 \%)$ & 0.982 \\
\hline \multicolumn{10}{|l|}{ Allele } \\
\hline$C$ & $428(52.3 \%)$ & $371(52.8 \%)$ & & $319(53.2 \%)$ & 194(54.2\%) & & $115(52.8 \%)$ & $177(51.5 \%)$ & \\
\hline $\mathrm{T}$ & $390(47.7 \%)$ & $331(47.2 \%)$ & 0.838 & $287(47.8 \%)$ & $164(45.8 \%)$ & 0.641 & $103(47.2 \%)$ & $167(48.5 \%)$ & 0.993 \\
\hline
\end{tabular}

CAD, coronary artery disease; SNP, single-nucleotide polymorphism.

Table 5 shows the distribution of the genotypes and alleles for rs1996147 of the Egr3 gene in the Han and Uygur populations. Both in the CAD patients and in the control subjects, the distribution of genotype and alleles is significantly different in the two ethnic populations (all $P<0.001$ ).

To further investigate the functional role of the rs1996147 genotypes associated with CAD in the Uygur, multivariable logistic regression analysis was performed
(Table 6). In total subjects and males, following adjustments for the serum concentration of total cholesterol, LDL-C, and HDL-C, diabetes mellitus, essential hypertension, and smoking, the significance of the recessive model (AA vs $\mathrm{GG}+\mathrm{AG}$ ) between patients with CAD and control participants was retained (total: $\mathrm{OR}=1.705$, 95\% CI: $1.166-2.494, P=0.006$; males: $\mathrm{OR}=1.908,95 \%$ CI: $1.189-3.062, P=0.007)$. 
Table 4 Genotyping and allele distributions in control subjects and patients with CAD in the Uygur population

\begin{tabular}{|c|c|c|c|c|c|c|c|c|c|}
\hline \multirow[b]{2}{*}{ Variants } & \multicolumn{3}{|c|}{ Total } & \multicolumn{3}{|c|}{ Men } & \multicolumn{3}{|c|}{ Women } \\
\hline & $\begin{array}{c}\text { CAD } \\
\text { patients }\end{array}$ & $\begin{array}{l}\text { Control } \\
\text { subjects }\end{array}$ & $P$ value & $\begin{array}{c}\text { CAD } \\
\text { patients }\end{array}$ & $\begin{array}{l}\text { Control } \\
\text { subjects }\end{array}$ & $P$ value & $\begin{array}{c}\text { CAD } \\
\text { patients }\end{array}$ & $\begin{array}{l}\text { Control } \\
\text { subjects }\end{array}$ & $P$ value \\
\hline \multicolumn{10}{|c|}{ rs1996147 } \\
\hline \multicolumn{10}{|c|}{ Genotyping } \\
\hline AA & $109(36.5 \%)$ & $75(24.7 \%)$ & & 77(38.9\%) & $49(25.0 \%)$ & & $32(31.7 \%)$ & $26(24.3 \%)$ & \\
\hline$A G$ & $142(47.5 \%)$ & $156(51.5 \%)$ & & $90(45.5 \%)$ & $98(50.0 \%)$ & & $52(51.5 \%)$ & $58(54.2 \%)$ & \\
\hline GG & $48(16.0 \%)$ & $72(23.8 \%)$ & $0.003^{*}$ & $31(15.6 \%)$ & $49(25.0 \%)$ & $0.005^{*}$ & $17(16.8 \%)$ & $23(21.5 \%)$ & 0.433 \\
\hline \multicolumn{10}{|c|}{ Dominant model } \\
\hline GG & 48(16.0\%) & $72(23.8 \%)$ & & $31(15.6 \%)$ & $49(25.0 \%)$ & & $17(16.8 \%)$ & $23(21.5 \%)$ & \\
\hline$A A+A G$ & $251(84.0 \%)$ & $231(76.2 \%)$ & $0.018^{*}$ & 167(84.4\%) & $147(75.0 \%)$ & $0.021^{*}$ & 84(83.2\%) & $84(78.5 \%)$ & 0.394 \\
\hline \multicolumn{10}{|c|}{ Recessive model } \\
\hline AA & $109(36.5 \%)$ & $75(24.7 \%)$ & & 77(38.9\%) & $49(25.0 \%)$ & & $32(31.7 \%)$ & $26(24.3 \%)$ & \\
\hline $\mathrm{GG}+\mathrm{AG}$ & 190(63.5\%) & $228(75.3 \%)$ & $0.002^{*}$ & 121(61.1\%) & $147(75.0 \%)$ & $0.003^{*}$ & 69(68.3\%) & $81(75.7 \%)$ & 0.235 \\
\hline \multicolumn{10}{|c|}{ Additive model } \\
\hline$A G$ & $142(47.5 \%)$ & $156(51.5 \%)$ & & $90(45.5 \%)$ & $98(50.0 \%)$ & & $52(51.5 \%)$ & $58(54.2 \%)$ & \\
\hline$A A+G G$ & $157(52.5 \%)$ & $147(48.5 \%)$ & 0.327 & $108(54.5 \%)$ & $98(50.0 \%)$ & 0.366 & 49(48.5\%) & 49(45.8\%) & 0.694 \\
\hline \multicolumn{10}{|l|}{ Allele } \\
\hline A & $360(60.2 \%)$ & $306(50.5 \%)$ & & $244(61.6 \%)$ & 196(50.0\%) & & $116(57.4 \%)$ & $110(51.4 \%)$ & \\
\hline G & 238(39.8\%) & $300(49.5 \%)$ & $0.001^{*}$ & 152(38.4\%) & $196(50.0 \%)$ & $0.001^{*}$ & $86(42.6 \%)$ & 104(48.6\%) & 0.218 \\
\hline \multicolumn{10}{|c|}{ rs1008949 } \\
\hline \multicolumn{10}{|c|}{ Genotyping } \\
\hline $\mathrm{CC}$ & $118(39.5 \%)$ & 104(34.3\%) & & 77(38.9\%) & 66(33.7\%) & & $41(40.6 \%)$ & $38(35.5 \%)$ & \\
\hline $\mathrm{CT}$ & $136(45.5 \%)$ & $152(50.2 \%)$ & & $95(48.0 \%)$ & $98(50.0 \%)$ & & $41(40.6 \%)$ & $54(50.5 \%)$ & \\
\hline$\pi$ & $45(15.0 \%)$ & $47(15.5 \%)$ & 0.409 & 26(13.1\%) & $32(16.3 \%)$ & 0.472 & 19(18.8\%) & $15(14.0 \%)$ & 0.334 \\
\hline \multicolumn{10}{|c|}{ Dominant model } \\
\hline $\mathrm{CC}$ & $118(39.5 \%)$ & 104(34.3\%) & & 77(38.9\%) & 66(33.7\%) & & $41(40.6 \%)$ & $38(35.5 \%)$ & \\
\hline$T+C T$ & $181(60.5 \%)$ & 199(65.7\%) & 0.191 & $121(61.1 \%)$ & $130(66.3 \%)$ & 0.282 & 60(59.4\%) & $69(64.5 \%)$ & 0.451 \\
\hline \multicolumn{10}{|c|}{ Recessive model } \\
\hline$\pi$ & $45(15.0 \%)$ & $47(15.5 \%)$ & & 26(13.1\%) & $32(16.3 \%)$ & & 19(18.8\%) & $15(14.0 \%)$ & \\
\hline $\mathrm{CC}+\mathrm{CT}$ & 254(85.0\%) & $256(84.5 \%)$ & 0.875 & 172(86.9\%) & 164(83.7\%) & 0.371 & $82(81.2 \%)$ & $92(86.0 \%)$ & 0.350 \\
\hline \multicolumn{10}{|c|}{ Additive model } \\
\hline CT & $136(45.5 \%)$ & $152(50.2 \%)$ & & $95(48.0 \%)$ & $98(50.0 \%)$ & & $41(40.6 \%)$ & $54(50.5 \%)$ & \\
\hline$C C+\pi$ & $163(54.5 \%)$ & $151(49.8 \%)$ & 0.267 & $103(52.0 \%)$ & $98(50.0 \%)$ & 0.688 & 60(59.4\%) & $53(49.5 \%)$ & 0.153 \\
\hline \multicolumn{10}{|l|}{ Allele } \\
\hline$C$ & $372(62.2 \%)$ & $360(59.4 \%)$ & & $249(62.9 \%)$ & $230(58.7 \%)$ & & 123(60.9\%) & $130(60.7 \%)$ & \\
\hline $\mathrm{T}$ & $226(37.8 \%)$ & $246(40.6 \%)$ & 0.319 & 147(37.1\%) & $162(41.3 \%)$ & 0.227 & 79(39.1\%) & 84(39.3\%) & 0.976 \\
\hline
\end{tabular}

CAD, coronary artery disease; SNP, single-nucleotide polymorphism; ${ }^{*} P<0.05$.

\section{Discussion}

Egr3 is a member of the Egr family, whose members are rapidly induced by extracellular stimuli and have been implicated in the proliferation and differentiation of several different cell types, including endothelial cells. The Egr3 gene, located on chromosome 8p21.3, was cloned from a serum-activated cDNA library $[21,22]$ and was originally described as a T-cell receptor-induced cyclosporine
A-sensitive factor responsible for the upregulation of Fas ligand (FasL) [23]. Although Egr3 has been studied primarily in the context of lymphocyte and neuromuscular development, recent evidence points to a role for Egr3 in transducing signals in endothelial cells. For example, previous studies [24,25] have shown that Egr3 is one of the most highly inducible genes in VEGFtreated endothelial cells. Liu D et al. [7] reported that 
Table 5 Genotyping and allele distributions in the Han and Uygur population (rs1996147)

\begin{tabular}{|c|c|c|c|c|c|c|}
\hline \multirow[b]{2}{*}{ Variants } & \multicolumn{3}{|c|}{ CAD patients } & \multicolumn{3}{|c|}{ Control subjects } \\
\hline & Han population & Uygur population & $P$ value & Han population & Uygur population & $P$ value \\
\hline \multicolumn{7}{|c|}{ Genotyping } \\
\hline AA & $45(11.0 \%)$ & 109(36.5\%) & & $49(14.0 \%)$ & $75(24.7 \%)$ & \\
\hline$A G$ & 199(48.7\%) & $142(47.5 \%)$ & & $156(44.4 \%)$ & $156(51.5 \%)$ & \\
\hline GG & $165(40.3 \%)$ & $48(16.0 \%)$ & $<0.001^{*}$ & $146(41.6 \%)$ & $72(23.8 \%)$ & $<0.001^{*}$ \\
\hline \multicolumn{7}{|l|}{ Allele } \\
\hline A & $289(35.3 \%)$ & $360(60.2 \%)$ & & $254(36.2 \%)$ & $306(50.5 \%)$ & \\
\hline G & $529(64.7 \%)$ & 238(39.8\%) & $<0.001^{*}$ & $448(63.8 \%)$ & $300(49.5 \%)$ & $<0.001^{*}$ \\
\hline
\end{tabular}

CAD, coronary artery disease; SNP, single-nucleotide polymorphism; * $P<0.05$.

Egr3, most likely together with other Egr isoforms, plays an important role in angiogenesis. VEGF is essential for endothelial cell differentiation and angiogenesis during development and plays a major role in neovascularisation in a variety of disease states [26]. Lyn D et al. [12] reported that a cDNA mouse expression array containing 588 genes representing diverse biological functions was used to simultaneously compare changes in gene expression after $24 \mathrm{~h}$ of ischemia with heart tissue from sham-operated mice. The cDNA array experimental approach provided a global profile of gene expression changes in the heart ventricle tissue after coronary artery occlusion. Moreover, the expression of Egr 1 and Egr 3 was induced by ischemia. The mechanism by which Egr3 may be associated with CAD remains unclear.

In the present study, there was a significant difference in the genotypic distribution of rs 1996147 between CAD patients and control subjects in the Uygur. We found that the Egr3 polymorphisms (rs1996147) were associated with a risk of CAD in the Uygur population. For total participants and males in the Uygur group, the A allele frequency was higher in CAD patients than in control subjects. This implies that the risk of CAD is increased with the presence of the A allele in the Uygur population. Similarly, the distribution of the rs1996147 recessive model (AA vs $\mathrm{GG}+\mathrm{AG}$ ) was significantly higher in the patients with CAD than in the control subjects. The significant difference in the recessive model between the two groups still existed after the multivariate adjustment of confounding factors, such as plasma concentration of TC, HDL and LDL, incidence of hypertension, diabetes, and smoking. This result indicated that the risk of CAD may increase in Uygur males with the presence of AA at rs1996147. However, in our study, Uygur females did not display a difference in the allele frequency or genotypic distribution between CAD patients and control participants. This result may be related to the small sample size of Uygur females. However, the distribution of rs1996147 genotypes, dominant model, recessive model, and allele frequency showed no significant differences between the patients with $C A D$ and the control participants in the Han group $(P>0.05)$.

The distribution of rs1008949 genotypes, dominant model, recessive model, and allele frequency did not show significant difference between the patients with CAD and the control subjects in the Han and Uygur groups. Our study is the first case-control study to investigate the association between the human Egr3 gene and CAD in the Uygur and Han in western China.

In conclusion, our study demonstrated that the rs1996147 polymorphism of the Egr3 gene was associated with CAD in males of the Chinese Uygur population. Males with the A allele might have a higher risk for CAD than those with the GG genotype. A larger sample size casecontrol study is required to investigate the relationship

Table 6 Multiple logistic regression analysis for CAD patients and control subjects in the Uygur population (rs1996147)

\begin{tabular}{|c|c|c|c|c|c|c|c|c|c|}
\hline \multirow[b]{2}{*}{ Risk factors } & \multicolumn{3}{|c|}{ Total } & \multicolumn{3}{|c|}{ Men } & \multicolumn{3}{|c|}{ Women } \\
\hline & Odd ratios & $95 \% \mathrm{Cl}$ & $P$ value & Odd ratios & $95 \% \mathrm{Cl}$ & $P$ value & Odd ratios & $95 \% \mathrm{Cl}$ & $P$ value \\
\hline Recessive model(AA vs GG + AG) & 1.705 & $1.166-2.494$ & $0.006^{*}$ & 1.908 & $1.189-3.062$ & $0.007^{*}$ & 1.353 & $0.694-2.637$ & 0.375 \\
\hline DM & 1.363 & $0.85-2.184$ & 0.199 & 1.442 & $0.787-2.64$ & 0.236 & 1.288 & $0.589-2.816$ & 0.525 \\
\hline Hypertension & 1.209 & $0.849-1.723$ & 0.293 & 1.205 & $0.772-1.88$ & 0.413 & 1.206 & $0.666-2.187$ & 0.536 \\
\hline $\mathrm{TC}$ & 1.864 & $1.486-2.338$ & $<0.001^{*}$ & 2.268 & $1.684-3.057$ & $<0.001^{*}$ & 1.415 & $0.947-2.114$ & $0.09^{*}$ \\
\hline LDL & 1.046 & $0.856-1.278$ & 0.662 & 1.017 & $0.806-1.282$ & 0.887 & 1.122 & $0.697-1.805$ & 0.636 \\
\hline $\mathrm{HDL}$ & 0.413 & $0.222-0.766$ & $0.005^{*}$ & 0.469 & $0.221-0.99$ & $0.047^{*}$ & 0.354 & $0.117-1.067$ & 0.065 \\
\hline Smoking & 2.657 & $1.877-3.763$ & $<0.001^{*}$ & 2.404 & $1.535-3.062$ & $<0.001^{*}$ & 3.447 & $1.811-6.559$ & $<0.001^{*}$ \\
\hline
\end{tabular}

CAD, coronary artery disease; DM, diabetes mellitus; TC, total cholesterol; LDL, Low-density lipoprotein; HDL, high-density lipoprotein; ${ }^{*} P<0.05$. 
between the rs1996147 polymorphism of the Egr3 gene and $\mathrm{CAD}$ in females of the Uygur population. Additional studies need to be undertaken to clarify the underlying molecular mechanism that associates the Egr3 polymorphisms with CAD.

\section{Competing interests}

The authors declare that they have no competing interests.

\section{Authors' contributions}

$X L$ and $X X$ carried out the molecular genetic studies and drafted the manuscript. YNY, XM and YYZ carried out the genotyping. SP and BDC participated in the design of the study and performed the statistical analysis. YTM, FL and XL conceived the study and participated in its design and coordination and helped to draft the manuscript. All authors read and approved the final manuscript.

\section{Acknowledgements}

This work was supported by grants from the Technology Support Program of Xinjiang Uygur Autonomous Region (No.201233138).

\section{Author details}

'Department of Cardiology, First Affiliated Hospital of Xinjiang Medical University, Urumqi, Xinjiang 830054, China. ${ }^{2}$ Xinjiang Key Laboratory of Cardiovascular Disease Research, Urumqi, Xinjiang 830054, China.

Received: 14 February 2014 Accepted: 16 May 2014

Published: 21 May 2014

\section{References}

1. Frazier L, Johnson RL, Sparks E: Genomics and cardiovascular disease. J Nurs Scholarsh 2005, 37:315-321.

2. Ge D, Zhu H, Huang Y, Treiber FA, Harshfield GA, Snieder H, Dong Y: Multilocus analyses of reninangiotensin- aldosterone system gene variants on blood pressure at rest and during behavioral stress in young normotensive subjects. Hypertension 2007, 49:107-112.

3. Humphries SE, Cooper JA, Talmud PJ, Miller GJ: Candidate gene genotypes, along with conventional risk factor assessment, improve estimation of coronary heart disease risk in healthy UK men. Clin Chem 2007, 53:8-16.

4. Crawford DC, Sanders CL, Qin X, Smith JD, Shephard C, Wong M, Witrak L, Rieder MJ: Genetic variation is associated with C-reactive protein levels in the Third National Health and Nutrition Examination Survey. Circulation 2006, 114:2458-2465.

5. Knowles JW, Wang H, Itakura $H$, Southwick A, Myers RM, Iribarren C, Fortmann SP, Go AS, Quertermous T, Hlatky MA: Association of polymorphisms in platelet and hemostasis system genes with acute myocardial infarction. Am Heart J 2007, 154:1052-1058.

6. Suehiro J, Hamakubo T, Kodama T, Aird WC, Minami T: Vascular endothelial growth factor activation of endothelial cells is mediated by early growth response-3. Blood 2010, 115:2520-2532.

7. Liu D, Evans I, Britton G, Zachary I: The zinc-finger transcription factor, early growth response 3 , mediates VEGF-induced angiogenesis. Oncogene 2008, 27:2989-2998.

8. Harja E, Bucciarelli LG, Lu Y, Stern DM, Zou YS, Schmidt AM, Yan SF: Early growth response-1 promotes atherogenesis: mice deficient in early growth response-1 and apolipoprotein E display decreased atherosclerosis and vascular inflammation. Circ Res 2004, 94:333-339.

9. Fahmy RG, Dass CR, Sun LQ, Chesterman CN, Khachigian LM: Transcription factor Egr-1 supports FGF-dependent angiogenesis during neovascularization and tumor growth. Nat Med 2003, 9:1026-1032.

10. Celletti FL, Waugh JM, Amabile PG, Brendolan A, Hilfiker PR, Dake MD: Vascular endothelial growth factor enhances atherosclerotic plaque progression. Nat Med 2001, 7:425-429.

11. Van Belle E, Tio FO, Chen D, Maillard L, Chen D, Kearney M, Isner JM: Passivation of metallic stents after arterial gene ransfer of phVEGF165 inhibits thrombus formation and intimal thickening. J Am Coll Cardiol 1997, 29:1371-1379.

12. Lyn D, Liu X, Bennett NA, Emmett NL: Gene expression profile in mouse myocardium after ischemia. Physiol Genomics 2000, 2:93-100.
13. Xie X, Ma Y-T, Yang Y-N, Li XM, Liu F, Huang D, Fu ZY, Ma X, Chen BD, Huang Y: Alcohol Consumption and Ankle-to-Brachial Index: Results from the Cardiovascular Risk Survey. PLoS ONE 2010, 5:e15181.

14. Pan S, Yu ZX, Ma YT, Ma YT, Liu F, Yang YN, Ma X, Fu ZY, Li XM, Xie X, Chen Y, Chen B, He CH: Appropriate Body Mass Index and Waist Circumference Cutoffs for Categorization of Overweight and Central Adiposity among Uighur Adults in Xinjiang. PLOS ONE 2013, 5:e80185.

15. Xie X, Ma YT, Fu ZY, Yang YN, Xiang M, Chen BD, Wang YH, Fen L: Haplotype Analysis of the CYP8A1 gene associated with myocardial infarction. Clin Appl Thromb Hem 2009, 15:574-580.

16. Pan S, Nakayama T, Sato N, Izumi Y, Soma M, Aoi N, Ma Y, Hinohara S, Doba $\mathrm{N}$ : A haplotype of the GOSR2 gene is associated with myocardial infarction in Japanese men. Genet Test Mol Biomarkers 2013, 17:481-8.

17. Yang YN, Wang XL, Ma YT, Xie X, Fu ZY, Li XM, Chen BD, Liu F: Association of interaction between smoking and CYP 2C19*3 polymorphism with coronary artery disease in a Uighur population. Clin Appl Thromb Hemost 2010, 16:579-83.

18. Xie X, Ma YT, Fu ZY, Yang YN, Ma X, Chen BD, Wang YH, Liu F: Association of polymorphisms of PTGS2 and CYP8A1 with myocardial infarction. Clin Che. Lab Med 2009, 47:347-352.

19. Pan S, Nakayama T, Sato N, Izumi Y, Soma M, Aoi N, Ma Y: A haplotype of the GOSR2 gene is associated with essential hypertension in Japanese men. Clin Biochem 2013, 46:760-765.

20. Sano M, Kuroi N, Nakayama T, Sato N, Izumi Y, Soma M, Kokubun S: The association study of calcitonin-receptor-like receptor gene in essential hypertension. Am J Hypertens 2005, 18:403-408.

21. Patwardhan S, Gashler A, Siegel MG, Chang LC, Joseph LJ, Shows TB, Le Beau MM, Sukhatme VP: EGR3, a novel member of the Egr family of genes encoding immediate-early transcription factors. Oncogene 1991, 6:917-928.

22. Lee SL, Sadovsky Y, Swirnoff AH, Polish JA, Goda P, Gavrilina G, Milbrandt J: Luteinizing hormone deficiency and female infertility in mice lacking the transcription factor NGFI-A (Egr-1). Science 1996, 273:1219-1221.

23. Mittelstadt PR, Ashwell JD: Cyclosporin A-sensitive transcription factor Egr-3 regulates Fas ligand expression. Mol Cell Biol 1998, 18:3744-3751.

24. Liu D, Jia H, Holmes DI, Stannard A, Zachary I: Vascular endothelial growth factor-regulated gene expression in endothelial cells: KDRmediated induction of Egr3 and the related nuclear receptors Nur77, Nurr1, and Nor1. Arterioscler Thromb Vasc Biol 2003, 23:2002-2007.

25. Minami T, Horiuchi K, Miura M, Abid MR, Takabe W, Noguchi N, Kohro T, Ge X, Aburatani H, Hamakubo T, Kodama T, Aird WC: Vascular endothelial growth factor- and thrombin-induced termination factor, Down syndrome critical region-1, attenuates endothelial cell proliferation and angiogenesis. J Biol Chem 2004, 279:50537-50554.

26. Ferrara N: Role of vascular endothelial growth factor in regulation of physiological angiogenesis. Am J Physiol Cell Physiol 2001, 280:1358-1366.

doi:10.1186/1476-511X-13-84

Cite this article as: Li et al:: Association of Egr3 genetic polymorphisms and coronary artery disease in the Uygur and Han of China. Lipids in Health and Disease 2014 13:84.

\section{Submit your next manuscript to BioMed Central and take full advantage of:}

- Convenient online submission

- Thorough peer review

- No space constraints or color figure charges

- Immediate publication on acceptance

- Inclusion in PubMed, CAS, Scopus and Google Scholar

- Research which is freely available for redistribution 